\title{
What makes people decide who to turn to when faced with a mental health problem? Results from a French survey
} Viviane Kovess-Masféty*1, Delphine Saragoussi ${ }^{1}$, Christine Sevilla-Dedieu ${ }^{1}$, Fabien Gilbert ${ }^{1}$, Agnieszka Suchocka ${ }^{1}$, Nathalie Arveiller ${ }^{2}$, Isabelle Gasquet ${ }^{3}$, Nadia Younes $^{2}$ and Marie-Christine Hardy-Bayle ${ }^{2}$

Address: ${ }^{1}$ MGEN Foundation for Public Health; EA 4069 University of Paris 5, 3 square Max Hymans, 75748 Paris Cedex 15, France, ${ }^{2}$ Versailles Hospital, 177 rue de Versailles, 78157 Le Chesnay Cedex, France and ${ }^{3}$ Medical Policy Division (AP-HP), 3 avenue Victoria, 75184 Paris Cedex 04 , France

Email: Viviane Kovess-Masféty* - vkovess@mgen.fr; Delphine Saragoussi - delsara@club-internet.fr; Christine Sevilla-Dedieu - csevilla@mgen.fr; Fabien Gilbert - fgilbert@mgen.fr; Agnieszka Suchocka - agnieszka.capuano@curie.net; Nathalie Arveiller - nathaliearveiller@yahoo.fr; Isabelle Gasquet - isabelle.gasquet@sap.aphp.fr; Nadia Younes - NYOUNES@ch-versailles.fr; Marie-Christine Hardy-Bayle - MCHardyBayle@chversailles.fr

* Corresponding author

Published: 31 July 2007

BMC Public Health 2007, 7:188 doi:10.1 186/147|-2458-7-188
Received: 9 January 2007

Accepted: 3I July 2007

This article is available from: http://www.biomedcentral.com/I47I-2458/7//88

(c) 2007 Kovess-Masféty et al; licensee BioMed Central Ltd.

This is an Open Access article distributed under the terms of the Creative Commons Attribution License (http://creativecommons.org/licenses/by/2.0), which permits unrestricted use, distribution, and reproduction in any medium, provided the original work is properly cited.

\begin{abstract}
Background: The unequal use of mental health care is a great issue, even in countries with universal health coverage. Better knowledge of the factors that have an impact on the pathway to mental health care may be a great help for designing education campaigns and for best organizing health care delivery. The objective of this study is to explore the determinants of help-seeking intentions for mental health problems and which factors influence treatment opinions and the reliance on and compliance with health professionals' advice.
\end{abstract}

Methods: $44 \mathrm{I}$ adults aged 18 to 70 were randomly selected from the general population of two suburban districts near Paris and agreed to participate in the study (response rate $=60.4 \%$ ). The 412 respondents with no mental health problems based on the CIDI-SF and the CAGE, who had not consulted for a mental health problem in the previous year, were asked in detail about their intentions to seek help in case of a psychological disorder and about their opinion of mental health treatments. The links between the respondents' characteristics and intentions and opinions were explored.

Results: More than half of the sample (57.8\%) would see their general practitioner (GP) first and $46.6 \%$ would continue with their GP for follow-up. Mental health professionals were mentioned far less than GPs. People who would choose their GP first were older and less educated, whereas those who would favor mental health specialists had lower social support. For psychotherapy, respondents were split equally between seeing a GP, a psychiatrist or a psychologist. People were reluctant to take psychotropic drugs, but looked favorably on psychotherapy.

Conclusion: GPs are often the point of entry into the mental health care system and need to be supported. Public information campaigns about mental health care options and treatments are needed to educate the public, eliminate the stigma of mental illness and eliminate prejudices. 


\section{Background}

There has been major concern about the unequal use of mental health care, even in countries with universal coverage such as Canada [1] where, despite such coverage, people from higher socioeconomic backgrounds receive more psychiatric care than those from lower socioeconomic backgrounds for equivalent mental health problems.

In addition to universal coverage, mental health literacy has been established as an important factor in the provision of adequate care, not only for people to be able to recognize specific disorders, but also for them to believe help is possible and available. People need to have the right information and knowledge about the professionals available, as well as about the different types of treatment [2]. In turn, their beliefs seem to be influenced by the improvements made to the mental health care system, such as an increase in psychotherapies available and outpatient unlabeled treatments [3]. On the other hand, a huge amount of information has been disseminated among the public from non-scientific sources, such as newspapers and television [2]. This has led a majority of people to prefer psychotherapy and to disregard psychotropic drugs, in contradiction to most of the literature on outcome [2]. This trend has been observed in many different countries [4].

In developed countries, the general practitioner (GP) is most frequently the first contact [5-9] and plays an important role as an entry point into the system, followed by potential care from mental health specialists [10]. This is true even if the extent of referral to a specialist may significantly differ among countries [11]. Indeed, people suffering from mental health problems may turn to various providers to look for help, including GPs, mental health specialists - subdivided between medical (psychiatrists) and non-medical practitioners (psychologists and various psychotherapists) - or even social services or what is labeled as "alternative" medicine [11]. Moreover, some people prefer to rely on their family and friends, even when suffering from severe disorders $[2,3]$.

Although the use of mental health care was found in Europe to be only partially related to healthcare provision [11], some system-related factors may have an impact on the pathway to mental health care $[12,13]$. For instance, in some health care systems, access to mental health providers is conditional on a visit to a GP who acts as a gatekeeper. Other systems are less strict. On the other hand, financial aspects can also play a role. If free-of-charge or inexpensive care is available, this can lead people to turn to one resource rather than another [14].
Moreover, features specific to each patient, such as the level of social support, have been reported as playing an important role in the different pathways taken towards mental health care $[15,16]$. However, specific types of mental disorders (i.e., for example social phobia) may have a major impact on the level of social support as well. Being female, having a higher level of education, together with a high level of social support, seem to produce the best ingredients to receive treatment according to evidence-based literature [17].

Improved knowledge of these factors is of relevance to mental health care planners when designing education campaigns, as well as for delivering care [18]. This study covers the determinants of help-seeking intentions for mental health problems: selecting primary care versus specialized mental health or relying on one's own network. In addition, our study focuses on exactly what influences people's opinions on the different treatments available, and their reliance on and compliance with their GPs' advice since these professionals have become a major focus for implementing mental health awareness campaigns. This study, which is part of a European project $[19,20]$, is based on a phone survey of a general randomized population in two relatively wealthy suburbs in the Paris area, in a country where the density of professionals is high, the majority of mental health and primary care resources are available free-of-charge and access to care is virtually unrestricted.

\section{Methods \\ Sample}

The sample was constituted through telephone numbers randomly taken from the phone directories in two counties in the Paris suburbs (Yvelines and Essonne). Respondents were recruited between September 2001 and January 2002. One interviewee per household was selected using the Kish method [21]. Subjects included were aged 18 to 70 , had lived in the county for at least six months and were not institutionalized. Eligible individuals were asked to give their verbal consent to participate in a telephone interview. Written consent was requested only of those participating in the follow-up survey. Ethical approval was not required for this project.

The response rate was $60.4 \%$ and the number of respondents was 441 persons. Among them, 25 people $(5.7 \%)$ were excluded as they were detected as having one of the measured psychiatric diagnoses or had reported at least one contact with a provider for any mental health problem in the twelve previous months. Of the remaining 416 people, 4 did not answer the demographic questions, leading to a final sample of 412 . 


\section{Instruments}

The questionnaire was based on the CIDI-SF [22] to detect depression and generalized anxiety disorder and the CAGE [23] questionnaire to detect alcohol abuse. Subjects not diagnosed as having any disorder and who did not declare that they had consulted for a mental health problem during the last twelve months, were asked in detail about their intention to consult in the event they felt they were suffering from a mental health problem and their opinion about mental health care options available.

Nine questions concerning intentions and opinions towards help-seeking for psychological problems were especially designed for this study (Figure 1). The first three questions focused on the type of help people would seek in case of a mental health disorder. For each question, a list of health care providers was given to them. If necessary, the respondents were provided with definitions of mental health professionals (in order to avoid frequent confusion between psychiatrists who are medical doctors and psychologists who are not). The other questions were simple questions answered by "yes", "no" or "I don't know" concerning intentions and opinions towards GPs and psychotherapy.

The impact of social support on the subjects' intentions was evaluated using the Oslo 3-item social support scale [24], which has already proved to be feasible, reliable, and valid in other studies $[25,26]$. The questionnaire also covered basic demographic questions on gender, age, educational level, marital status and professional status.

\section{Statistical analysis}

The differences between ratios were measured using Chisquare tests. The statistical analyses were performed using StataSE 9 software.

\section{Results}

\section{Sample description}

Table 1 shows the characteristics of the sample. The majority of the respondents were female $(63.6 \%)$. The comparison of the characteristics between men and women revealed no significant difference on most of the variables, with the exception of professional status and social support. Women were less often employed and had a higher level of social support.

\section{Descriptive analyses}

Descriptive analyses (Table 2) show that more than half of the sample (57.8\%) would seek out a GP first in the event of psychological or behavioral difficulties, followed equally by a psychologist (15.1\%) and a psychiatrist $(14.6 \%)$. However, men and women differed on many aspects $(\mathrm{p}<0.01)$. Women would turn more to GPs (60.7\% vs. $52.7 \%)$ and psychologists (17.9\% vs. $10.0 \%)$, whereas men would rather see a psychiatrist (18.0\% vs. $12.6 \%)$ or their close friends and family (12.7\% vs. $4.2 \%)$. When asked about long-term care, half of the sample would turn to a GP (46.6\%) and in this case, no difference was identified between men and women $(p=0.15)$.

In response to the question, "Today, if you wanted to go into psychotherapy, who would you see?", the answers were equally divided among the different options. 15.1\% did not know, 22.3\% mentioned their GP (most likely with the idea that their GP would refer them to a therapist), followed by psychiatrists (22.3\%) and psychologists $(23.3 \%)$, who were mentioned approximately at the same rate. No difference between men and women was observed $(\mathrm{p}=0.48)$.

The marked preference of the majority of our sample for GPs shows the high level of trust patients have in them. Indeed, $79.1 \%$ of the respondents were ready to see a mental health professional referred to them by their GP. However, we did find that women would actually take their GPs' advice more easily than men (83.2\% vs. $72.0 \%$; $\mathrm{p}=0.03)$.

However, trusting a GP no longer seems to be the rule when it comes to psychotropic drug prescription: $36.4 \%$ of the sample stated they would not take a psychotropic drug prescribed by their GP and an additional 8\% did not know what they would do. In the end, only 55.6\% said "yes", they would take a psychotropic drug prescribed by their GP and once again, no difference was identified between men and women $(\mathrm{p}=0.57)$. This distrust in pharmaceutical drugs goes hand-in-hand with a general approval of psychotherapy, since $81.1 \%$ agreed that psychotherapy was needed in the event of a psychological disorder, with again no difference between men and women as regards this opinion ( $\mathrm{p}=0.12)$.

Nearly thirty percent $(27.7 \%)$ thought that GPs would be able to manage mental health disorders on their own. More than half (50.5\%), however, thought their GP had to work in cooperation with other professionals, but most of the respondents were unaware if their GP worked together with mental health professionals (60.7\%).

\section{Multiple regression analyses}

In order to evaluate what motivated the respondents' choices, we conducted multiple logistic regression analyses, adjusted for gender, for each of the questions using demographic variables, together with social network intensity measures.

In response to the question, "Today, if you wanted to consult a health professional for psychological difficulties or behavioral problems, who would you go to first?", we 


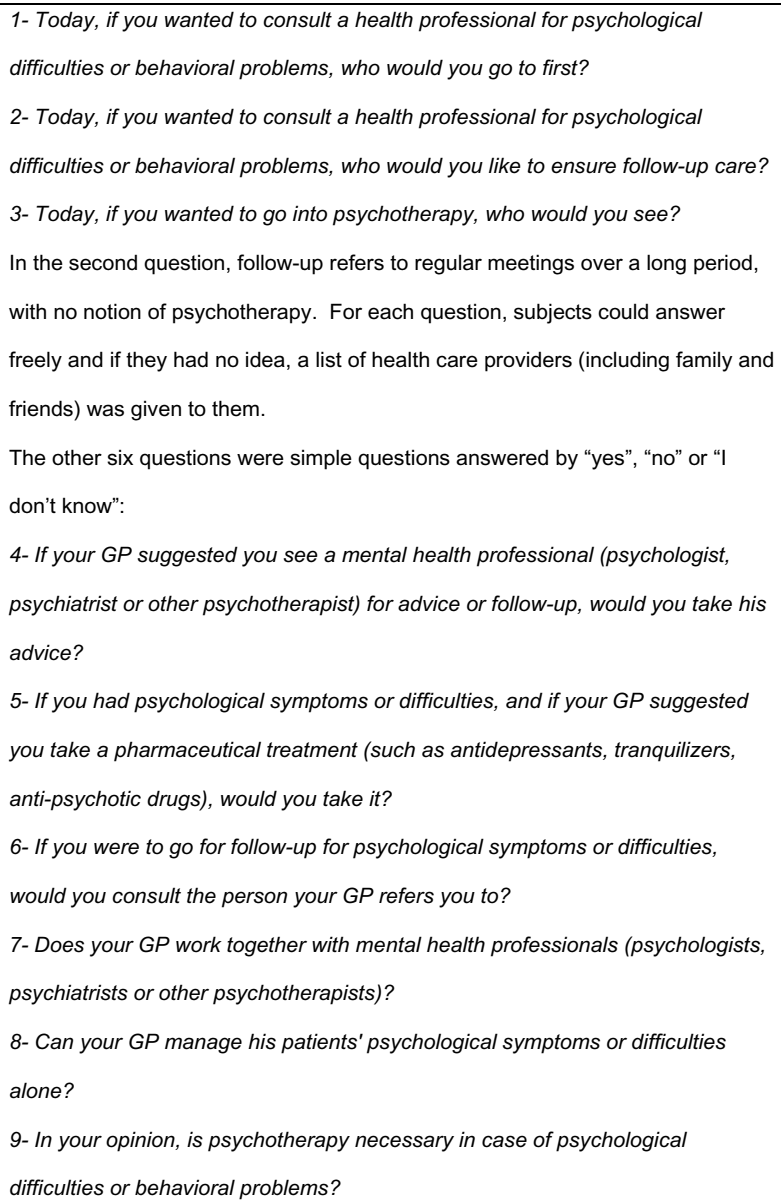

\section{Figure I}

Questions concerning intentions and opinions toward helpseeking for psychological problems.

looked initially at the probability of turning to a mental health provider versus a GP (Table 3 ). The results showed that older, as well as less educated people would turn more often to a GP, whereas those with a smaller social network favored mental health providers. When specific regressions were then performed for psychiatrists or psychologists versus a GP, respectively, age and social network were significant for psychologists, whereas educational level was significant for psychiatrists. When we subsequently looked at the probability of consulting a psychologist first versus a psychiatrist, our models showed that women would favor psychologists over psychiatrists $(\mathrm{OR}=3.05 ; \mathrm{p}=0.01)$, together with people with a smaller social network $(\mathrm{OR}=2.94 ; \mathrm{p}=0.02)$. Finally, when friends and family were compared to professional help, men clearly favored this option $(\mathrm{OR}=3.60 ; \mathrm{p}=0.00)$ over professionals, compared to women.
None of these determinants seemed to influence the opinion regarding psychotherapy with a preferred provider (psychologist vs. psychiatrist), with the exception of younger respondents who preferred psychologists $(\mathrm{OR}=$ $2.31 ; \mathrm{p}=0.04)$, and the distrust of psychotropic medication. Men, however, would not follow their GP's advice as easily as women when it comes to consulting a mental health care provider, and people with a reduced social network would behave the same way (Table 4). Finally, women seemed to believe more than men in psychotherapy as being necessary in case of psychological problems $(\mathrm{OR}=1.85 ; \mathrm{p}>0.05$ but just at 0.08$)$. Here the effect of social network is U-shaped: those in the middle were those who preferred to rely on psychotherapy the most.

\section{Discussion}

This study shows that the majority of a French sample from the Paris suburbs intends to consult a GP first for a mental health problem and would comply with their GP's advice if they suggest that a visit to a mental health care provider is necessary. Psychiatrists and psychologists are mentioned equally. Psychotherapies are considered as a necessity and almost half of the respondents distrust pharmaceutical drugs or are not sure if they will take them if prescribed. Age, gender, educational level and social network also have some influence on the intentions stated.

Concerning the preference of our sample for GPs, the French are identical to respondents in a number of developed countries. However, the percentage of people mentioning mental health care providers appeared to be higher than in the Michigan survey, where 13\% mentioned a psychiatrist and $10 \%$ a psychologist [7] and in the German survey, where respectively $10.4 \%$ and $9.8 \%$ mentioned specialist care as their first choice in case of depression [27]. However, this may be related to a higher density of psychiatrists in France [28].

Our survey shows that people who report their intention to consult a GP initially, as well as for follow-up are older (at least 50 years old) and less educated. Psychiatrists were chosen more often by those with a higher level of education (university level versus secondary only). This trend has been described in previous studies on attitudes and intentions in the United States and the Netherlands $[29,30]$, as well as in Germany [27]. Access to a psychiatrist may therefore depend on a certain level of education and age, since for older and less educated people, psychiatrists are linked more to mental illness and the stigma behind it.

Easy acceptance of a referral to a mental health care provider has not been found in previous literature, but could be compared to the high level of confidence reported in an Australian study [2]. However, this result is still surpris- 
Table I: Sample description

\begin{tabular}{|c|c|c|c|c|c|}
\hline \multirow[t]{2}{*}{ Characteristics } & \multicolumn{2}{|c|}{ Overall sample $(N=4 \mid 2)$} & \multirow{2}{*}{$\begin{array}{c}\text { Men }(\mathbf{N}=\mathbf{1 5 0}) \\
\%\end{array}$} & \multirow{2}{*}{$\begin{array}{c}\text { Women }(\mathbf{N}=\mathbf{2 6 2}) \\
\%\end{array}$} & \multirow[t]{2}{*}{$\mathbf{p}$} \\
\hline & $\mathbf{n}$ & $\%$ & & & \\
\hline \multicolumn{6}{|l|}{ Gender } \\
\hline Male & 150 & 36.4 & & & \\
\hline Female & 262 & 63.6 & & & \\
\hline Age & & & & & 0.50 \\
\hline $18-34$ & 109 & 26.5 & 28.2 & 23.3 & \\
\hline $35-49$ & 142 & 34.5 & 34.4 & 34.7 & \\
\hline$\geq 50$ & 161 & 39.1 & 37.4 & 42.0 & \\
\hline Educational level & & & & & 0.05 \\
\hline Primary, secondary* or vocational school & 105 & 25.5 & 24.0 & 26.3 & \\
\hline Secondary school** & 95 & 23.1 & 17.3 & 26.3 & \\
\hline University & 212 & 51.5 & 58.7 & 47.3 & \\
\hline Marital status & & & & & 0.06 \\
\hline Single & 114 & 27.7 & 30.7 & 26.0 & \\
\hline Married & 251 & 60.9 & 62.7 & 59.9 & \\
\hline Divorced or widowed & 47 & 11.4 & 6.7 & 14.1 & \\
\hline Origin & & & & & 0.37 \\
\hline French & 366 & 88.8 & 90.7 & 87.8 & \\
\hline Foreign & 46 & 11.2 & 9.3 & 12.2 & \\
\hline Professional status & & & & & $<0.01$ \\
\hline Employed & 265 & 64.3 & 70.0 & 61.1 & \\
\hline Retired & 72 & 17.5 & 20.7 & 15.7 & \\
\hline Other & 75 & 18.2 & 9.3 & 23.3 & \\
\hline Social support & & & & & 0.02 \\
\hline Low & 98 & 23.8 & 31.3 & 19.5 & \\
\hline Moderate & 245 & 59.5 & 53.3 & 63.0 & \\
\hline High & 69 & 16.8 & 15.3 & 17.6 & \\
\hline
\end{tabular}

$*=$ for students aged II to 14

** $=$ for students aged 15 to 17

ing, since in France, GP referral to mental health care professionals was found to be the lowest in a study comparing six European countries [11]. This finding underlines that in France, the problem is due more to our GPs' attitudes and beliefs than their patients.

Being a man or a woman seems to have a high impact on whether or not a GP's advice to consult a mental health care provider is complied with. Women are two times more likely to follow this advice compared to men. In addition, women are more inclined to visit a psychologist and men more inclined to see a psychiatrist. This may be explained by a higher propensity of women to talk about their problems, whereas men may prefer what they see as a more medical approach, such as a visit to a psychiatrist. Based on this hypothesis, women are slightly more in favor of psychotherapy than men $(p=0.08)$. Compared to women, men more frequently mentioned their family and friends versus any provider and this may reflect reluctance to accept a mental health care approach.

Social support has been found to play a key role in the choice of a provider. Respondents with a low level of social support clearly favor psychologists versus GPs, but also psychologists versus psychiatrists. This could be interpreted as a desire to talk about psychological difficulties rather than taking a more medical approach. People who claim they have a poor social network are less likely to rely on their friends and family in case of problems which seems only logical and this applies especially to men, who generally prefer this type of help. Respondents who have a low level of social support stated they did not want to comply with a mental health referral from their GP, but this concerned women only and is consistent with the belief that psychotherapy is a better approach. However, this contradicts their preference to see a psychologist rather than a GP. This may be due to the fact that people with a limited social network clearly favor psychologists over psychiatrists and that respondents may have mixed up the two professionals when asked about a referral to a mental health care provider. Those who do not prefer psychotherapy to solve psychological problems benefit from strong social support compared to those who have a moderate level of social support. This may be interpreted as reliance on their own network to solve problems. However, it must be kept in mind that those who have the 
Table 2: Frequency of answers to the 9 questions about intentions and opinions toward help-seeking for psychological problems

\begin{tabular}{|c|c|c|c|c|c|c|c|c|c|c|c|c|}
\hline & \multicolumn{4}{|c|}{ Who would you go to first? } & \multicolumn{4}{|c|}{$\begin{array}{l}\text { Who would you like to ensure } \\
\text { follow-up care? }\end{array}$} & \multicolumn{4}{|c|}{$\begin{array}{l}\text { If you wanted to go into psychotherapy, } \\
\text { who would you see? }\end{array}$} \\
\hline & & & \multicolumn{2}{|c|}{$p<0.01$} & & & \multicolumn{2}{|c|}{$p=0.15$} & & & \multicolumn{2}{|c|}{$p=0.48$} \\
\hline & \multicolumn{2}{|c|}{$\begin{array}{l}\text { Overall Sample } \\
\qquad(\mathbf{N}=4 \mid 2)\end{array}$} & \multirow{2}{*}{$\begin{array}{c}\begin{array}{c}\text { Men } \\
(\mathbf{N}=150)\end{array} \\
\%\end{array}$} & \multirow{2}{*}{$\begin{array}{c}\begin{array}{c}\text { Women } \\
(\mathbf{N}=\mathbf{2 6 2})\end{array} \\
\%\end{array}$} & \multicolumn{2}{|c|}{$\begin{array}{l}\text { Overall Sample } \\
\qquad(N=4 \mid 2)\end{array}$} & \multirow{2}{*}{$\begin{array}{c}\begin{array}{c}\text { Men } \\
(\mathbf{N}=150)\end{array} \\
\%\end{array}$} & \multirow{2}{*}{$\begin{array}{c}\begin{array}{c}\text { Women } \\
(\mathbf{N}=\mathbf{2 6 2})\end{array} \\
\%\end{array}$} & \multicolumn{2}{|c|}{$\begin{array}{l}\text { Overall Sample } \\
\qquad(\mathbf{N}=4 \mid 2)\end{array}$} & \multirow{2}{*}{$\begin{array}{c}\begin{array}{c}\text { Men } \\
(\mathbf{N}=150)\end{array} \\
\%\end{array}$} & \multirow{2}{*}{$\begin{array}{c}\begin{array}{c}\text { Women } \\
(\mathbf{N}=\mathbf{2 6 2})\end{array} \\
\%\end{array}$} \\
\hline & $\mathbf{n}$ & $\%$ & & & $\mathbf{n}$ & $\%$ & & & $\mathbf{n}$ & $\%$ & & \\
\hline GP & 238 & 57.8 & 52.7 & 60.7 & 192 & 46.6 & 44.7 & 47.7 & 92 & 22.3 & 22.0 & 22.5 \\
\hline Psychiatrist & 60 & 14.6 & 18.0 & 12.6 & 69 & 16.8 & 19.3 & 15.3 & 92 & 22.3 & 22.0 & 22.5 \\
\hline Psychologist & 62 & 15.1 & 10.0 & 17.9 & 81 & 19.7 & 14.7 & 22.5 & 96 & 23.3 & 21.3 & 24.4 \\
\hline Friends/Family & 30 & 7.3 & 12.7 & 4.2 & - & - & - & - & - & - & - & - \\
\hline Other & 15 & 3.6 & 4.7 & 3.1 & 43 & 10.4 & 13.3 & 8.8 & 70 & 17.0 & 21.3 & 14.5 \\
\hline \multirow[t]{5}{*}{ Don't know } & 7 & 1.7 & 2.0 & 1.5 & 27 & 6.6 & 8.0 & 5.7 & 62 & 15.1 & 13.3 & 16.0 \\
\hline & \multicolumn{4}{|c|}{$\begin{array}{l}\text { If your GP suggested you see a mental } \\
\text { health professional, would you take his } \\
\text { advice? }\end{array}$} & \multicolumn{4}{|c|}{$\begin{array}{l}\text { If your GP suggested you take a } \\
\text { pharmaceutical treatment, } \\
\text { would you take it? }\end{array}$} & \multicolumn{4}{|c|}{$\begin{array}{l}\text { Would you consult the person your } \\
\text { GP refers you to? }\end{array}$} \\
\hline & & & \multicolumn{2}{|c|}{$p=0.03$} & & & \multicolumn{2}{|c|}{$p=0.57$} & & & \multicolumn{2}{|c|}{$p=0.13$} \\
\hline & \multicolumn{2}{|c|}{$\begin{array}{l}\text { Overall Sample } \\
\quad(N=4 \mid 2)\end{array}$} & $\begin{array}{c}\text { Men } \\
(N=150)\end{array}$ & $\begin{array}{c}\text { Women } \\
(\mathbf{N}=262)\end{array}$ & \multicolumn{2}{|c|}{$\begin{array}{l}\text { Overall Sample } \\
\qquad(N=4 \mid 2)\end{array}$} & $\begin{array}{c}\text { Men } \\
(N=150)\end{array}$ & $\begin{array}{l}\text { Women } \\
(\mathbf{N}=262)\end{array}$ & \multicolumn{2}{|c|}{$\begin{array}{l}\text { Overall Sample } \\
(\mathbf{N}=4 \mid 2)\end{array}$} & $\begin{array}{c}\text { Men } \\
(N=150)\end{array}$ & $\begin{array}{c}\text { Women } \\
(N=262)\end{array}$ \\
\hline & $\mathbf{n}$ & $\%$ & $\%$ & $\%$ & $\mathbf{n}$ & $\%$ & $\%$ & $\%$ & $\mathbf{n}$ & $\%$ & $\%$ & $\%$ \\
\hline Yes & 326 & 79.1 & 72.0 & 83.2 & 229 & 55.6 & 58.7 & 53.8 & 342 & 83.0 & 78.7 & 85.5 \\
\hline No & 66 & 16.0 & 22.0 & 12.6 & 150 & 36.4 & 34.7 & 37.4 & 51 & 12.4 & 16.7 & 9.9 \\
\hline \multirow[t]{5}{*}{ No opinion } & 20 & 4.9 & 6.0 & 4.2 & 33 & 8.0 & 6.7 & 8.8 & 19 & 4.6 & 4.7 & 4.6 \\
\hline & \multicolumn{4}{|c|}{$\begin{array}{l}\text { Does your GP work together with } \\
\text { mental health professionals? }\end{array}$} & \multicolumn{4}{|c|}{$\begin{array}{l}\text { Can your GP manage his patients' } \\
\text { psychological symptoms } \\
\text { or difficulties alone? }\end{array}$} & \multicolumn{4}{|c|}{$\begin{array}{l}\text { Is psychotherapy necessary in case of } \\
\text { psychological difficulties } \\
\text { or behavioral problems? }\end{array}$} \\
\hline & & & \multicolumn{2}{|c|}{$p=0.71$} & & & \multicolumn{2}{|c|}{$p=0.22$} & & & $p=$ & .12 \\
\hline & $\begin{array}{l}\text { Overa } \\
(\mathbf{N}\end{array}$ & $\begin{array}{l}\text { ample } \\
\text { 12) }\end{array}$ & $\begin{array}{c}\text { Men } \\
(N=150)\end{array}$ & $\begin{array}{l}\text { Women } \\
(\mathbf{N}=262)\end{array}$ & $\begin{array}{l}\text { Overa } \\
(\mathbf{N}\end{array}$ & $\begin{array}{l}\text { ample } \\
\text { 12) }\end{array}$ & $\begin{array}{c}\text { Men } \\
(N=150)\end{array}$ & $\begin{array}{l}\text { Women } \\
(\mathrm{N}=262)\end{array}$ & $\underset{(N)}{O}$ & $\begin{array}{l}\text { Sample } \\
\text { 4|2) }\end{array}$ & $\begin{array}{c}\text { Men } \\
(N=150)\end{array}$ & $\begin{array}{c}\text { Women } \\
(N=262)\end{array}$ \\
\hline & $\mathbf{n}$ & $\%$ & $\%$ & $\%$ & $\mathbf{n}$ & $\%$ & $\%$ & $\%$ & $\mathbf{n}$ & $\%$ & $\%$ & $\%$ \\
\hline Yes & 82 & 19.9 & 22.0 & 18.7 & 114 & 27.7 & 24.0 & 29.8 & 334 & 81.1 & 77.3 & 83.2 \\
\hline No & 80 & 19.4 & 19.3 & 19.5 & 208 & 50.5 & 50.0 & 50.8 & 41 & 10.0 & 14.0 & 7.6 \\
\hline No opinion & 250 & 60.7 & 58.7 & 61.8 & 90 & 21.8 & 26.0 & 19.5 & 37 & 9.0 & 8.7 & 9.2 \\
\hline
\end{tabular}

smallest social network are also those who have the highest number of symptoms [10].

Just as in other countries, French people would rather engage in psychotherapy than take psychotropic drugs $[31,32]$. People believe that psychiatric drugs are addictive, useless or solely useful for symptoms [33]. In France, this marked preference for non-pharmaceutical treatment over psychotropic drugs, however, is in contrast to the very high level of psychotropic drug consumption [34]. In France, $80 \%$ of psychotropic drug prescriptions and $70 \%$ of antidepressant prescriptions are drawn up by GPs and
$20 \%$ of these prescriptions meet no real psychiatric diagnosis [35]. The pressure on GPs, who are poorly trained to perform psychiatric diagnoses and who are overwhelmed by the demand without enough time to respond, has been put forward as an explanation for this, along with a lack of relations with mental health care specialists, together with their tendency to prescribe drugs in a generous public health insurance system.

It is also noteworthy that in general, people do not favor psychiatrists (whose fees are paid for by public health insurance) over psychologists (whose fees are not reim- 
Table 3: Factors influencing the likelihood of consulting first a psychiatrist or a psychologist versus a GP in case of psychological problems

\begin{tabular}{|c|c|c|c|c|c|c|c|c|c|}
\hline & \multicolumn{3}{|c|}{ Overall sample $(\mathrm{N}=360)$} & \multicolumn{3}{|c|}{$\operatorname{Men}(N=\mid 2 I)$} & \multicolumn{3}{|c|}{ Women $(N=239)$} \\
\hline & $\beta$ & OR & & $\beta$ & OR & & $\beta$ & OR & \\
\hline & $\beta$ SE & OR 95\%Cl & $\mathbf{p}$ & $\beta$ SE & OR 95\%Cl & $\mathbf{p}$ & $\beta$ SE & OR 95\%Cl & $\mathbf{p}$ \\
\hline \multicolumn{10}{|l|}{ Gender } \\
\hline Male & 0 & I & & & & & & & \\
\hline Female & -0.0200 .25 & $0.980 .60-1.60$ & 0.94 & & & & & & \\
\hline Age & & & 0.01 & & & 0.48 & & & 0.03 \\
\hline $18-34$ & -0.0040 .30 & $1.000 .55-1.80$ & 0.99 & 0.1260 .57 & $1.130 .37-3.44$ & 0.82 & -0.0490 .36 & $0.950 .47-1.94$ & 0.89 \\
\hline $35-49$ & 0 & I & & 0 & I & & 0 & I & \\
\hline$\geq 50$ & -0.7790 .28 & $0.460 .26-0.80$ & 0.01 & -0.4990 .47 & $0.610 .24-1.52$ & 0.29 & -0.9390 .37 & $0.390 .19-0.80$ & 0.01 \\
\hline Educational level & & & 0.15 & & & 0.79 & & & 0.22 \\
\hline $\begin{array}{l}\text { Primary, secondary* } \\
\text { or vocational school }\end{array}$ & -0.5810 .30 & $0.560 .31-1.00$ & 0.05 & -0.3390 .49 & $0.710 .27-1.87$ & 0.49 & -0.6860 .39 & $0.500 .23-1.09$ & 0.08 \\
\hline Secondary school** & -0.1890 .29 & $0.830 .47-1.47$ & 0.52 & -0.1490 .58 & $0.860 .28-2.69$ & 0.80 & -0.2000 .35 & $0.820 .41-1.62$ & 0.57 \\
\hline University & 0 & $\mathrm{I}$ & & 0 & 1 & & 0 & 1 & \\
\hline Marital status & & & 0.93 & & & 0.98 & & & 0.80 \\
\hline Single & 0.1050 .29 & $1.110 .63-1.96$ & 0.72 & -0.0920 .54 & $0.910 .32-2.63$ & 0.87 & 0.2350 .36 & $1.270 .63-2.54$ & 0.51 \\
\hline Married & 0 & 1 & & 0 & 1 & & 0 & 1 & \\
\hline Divorced or widowed & -0.0010 .38 & $1.000 .48-2.09$ & 1.00 & -0.0640 .76 & $0.940 .21-4.15$ & 0.93 & 0.0640 .44 & $1.070 .45-2.54$ & 0.88 \\
\hline Social support & & & 0.02 & & & 0.18 & & & 0.12 \\
\hline Low & $0.73 \mid 0.28$ & $2.081 .20-3.58$ & 0.01 & 0.7940 .45 & $2.210 .92-5.33$ & 0.08 & 0.6890 .37 & $1.990 .97-4.10$ & 0.06 \\
\hline Moderate & 0 & 1 & & 0 & I & & 0 & I & \\
\hline High & -0.0660 .32 & $0.940 .50-1.77$ & 0.84 & -0.0300 .59 & $0.970 .31-3.06$ & 0.96 & -0.1250 .40 & $0.880 .41-1.92$ & 0.75 \\
\hline
\end{tabular}

$*=$ for students aged $\mathrm{I} \mathrm{I}$ to 14

$* *=$ for students aged 15 to 17

bursed in the majority of cases). Barriers to seeking help from mental health care professionals seem to be more dependent on knowledge, beliefs and stigma than on financial resources, corroborating Bayer and Peay's work [36].

Admittedly, this study has several limitations. Our sample was rather small and skewed toward women, so it cannot be truly representative of the Paris suburban population, but we carefully performed analyses taking into account both genders separately. However, the men who agreed to participate in the survey may be different from those who refused and may be more prone to seeking psychiatric care. As respondents were selected from two Parisian suburbs, our sample could not be considered as representative of the French population either, although indeed this was not the aim. However, it may be that the high density of mental health care providers in the Parisian area had an influence on people's intentions. In addition, intentions may differ from what people will actually do in case of a problem. Certain studies, however, seem to establish that opinions on mental health care are structured based on availability and do contribute to what will happen $[18,36]$.

\section{Conclusion}

Considering the results of our study, efforts in mental health care planning should be aimed in two directions. The first would be to support GPs as the initial entry point into the mental health care system. This has many advantages. GPs are familiar with the behavior of their patients and people claim they would comply if their GP suggests they see a mental health professional, even though they would prefer to be cared for by their own GP. In this case, GPs could take care of minor psychological disorders and refer major problems to specialists. Thiswould also contribute to regulating the activity of our mental health care professionals. Thissolution goes back to the question of training GPs in psychiatry and that of the relationship between primary and secondary care systems, which could be enhanced through network approaches to make contacts easier and to reduce GPs' reluctance to call on mental health professionals [37]. The second would be to organize public information campaigns on mental health care and the difference between psychiatrists, psychologists and the various treatment options available in order to educate the public and reduce prejudices. Campaigns of this type have already been conducted in Great Britain and in Australia. In Great Britain, the Defeat Depression 
Table 4: Factors influencing the likelihood of not taking the GP's advice to see a mental health care professional

\begin{tabular}{|c|c|c|c|c|c|c|c|c|c|}
\hline & \multicolumn{3}{|c|}{ Overall sample $(\mathbf{N}=392)$} & \multicolumn{3}{|c|}{$\operatorname{Men}(N=|4|)$} & \multicolumn{3}{|c|}{ Women $(N=25 \mathrm{I})$} \\
\hline & $\beta$ & OR & & $\beta$ & OR & & $\beta$ & OR & \\
\hline & $\beta \mathbf{S E}$ & OR 95\%Cl & $\mathbf{p}$ & $\beta$ SE & OR 95\%Cl & $\mathbf{p}$ & $\beta$ SE & OR 95\%Cl & $\mathbf{p}$ \\
\hline \multicolumn{10}{|l|}{ Gender } \\
\hline Male & 0.6490 .29 & $1.91 \quad 1.09-3.37$ & 0.03 & & & & & & \\
\hline Female & 0 & 1 & & & & & & & \\
\hline Age & & & 0.37 & & & 0.15 & & & 0.96 \\
\hline $18-34$ & 0.5220 .40 & $1.690 .78-3.66$ & 0.19 & 1.1340 .60 & $3.110 .95-10.11$ & 0.06 & -0.1180 .55 & $0.890 .30-2.63$ & 0.83 \\
\hline $35-49$ & 0 & 1 & & 0 & 1 & & 0 & 1 & \\
\hline$\geq 50$ & 0.3690 .35 & $1.450 .73-2.86$ & 0.29 & 0.6790 .54 & $1.970 .69-5.65$ & 0.21 & 0.0340 .48 & $1.030 .4 \mathrm{I}-2.63$ & 0.94 \\
\hline Educational level & & & 0.19 & & & 0.49 & & & 0.22 \\
\hline $\begin{array}{l}\text { Primary, secondary* } \\
\text { or vocational school }\end{array}$ & 0.5530 .34 & $1.740 .90-3.37$ & 0.10 & 0.4750 .50 & $1.610 .60-4.29$ & 0.34 & 0.8120 .49 & $2.250 .86-5.87$ & 0.10 \\
\hline Secondary school** & 0.4960 .35 & I.64 0.82-3.29 & 0.16 & 0.5420 .54 & $1.720 .59-4.98$ & 0.32 & 0.6290 .49 & I.88 $0.7 \mid-4.93$ & 0.20 \\
\hline University & 0 & I & & 0 & I & & 0 & I & \\
\hline Marital status & & & 0.80 & & & 0.57 & & & 0.85 \\
\hline Single & 0.1000 .36 & I.II $0.55-2.22$ & 0.78 & 0.1410 .53 & $1.150 .40-3.28$ & 0.79 & 0.2420 .52 & $1.270 .46-3.54$ & 0.64 \\
\hline Married & 0 & 1 & & 0 & I & & 0 & I & \\
\hline Divorced or widowed & -0.2770 .49 & $0.760 .29-1.96$ & 0.57 & -1.079 I.II & $0.340 .04-2.97$ & 0.33 & -0.1530 .57 & $0.860 .28-2.60$ & 0.79 \\
\hline Social support & & & 0.03 & & & 0.79 & & & $<0.01$ \\
\hline Low & 0.7330 .31 & $2.08 \mathrm{I} . \mid 4-3.81$ & 0.02 & 0.3030 .46 & $1.350 .55-3.35$ & 0.51 & 1.2580 .43 & $3.52 \mathrm{I} .5 \mathrm{I}-8.20$ & $<0.01$ \\
\hline Moderate & 0 & 1 & & 0 & 1 & & 0 & 1 & \\
\hline High & -0.2060 .45 & $0.810 .34-1.97$ & 0.65 & -0.0160 .66 & $0.980 .27-3.56$ & 0.98 & -0.3170 .66 & $0.730 .20-2.68$ & 0.63 \\
\hline
\end{tabular}

$*$ = for students aged II to 14

$* *=$ for students aged 15 to 17

Campaign using the media as an information relay which took place between 1991 and 1996 led to a change of about $5-10 \%$ in terms of knowledge about mental health problems, antidepressants and intentions to consult health professionals $[38,39]$. These types of campaigns will be launched very soon in France.

\section{Abbreviations}

CAGE Cut down, Annoyed, Guilty, Eye-opener

CIDI-SF Composite International Diagnostic InterviewShort Form

\section{GP General Practitioner}

\section{Competing interests}

The author(s) declare that they have no competing interests.

\section{Authors' contributions}

VKM participated in the conception and design of the study and in the acquisition and interpretation of data, and extensively revised the draft of the article. DS participated in the analysis and interpretation of data, and drafted the article. CSD participated in the extensive revision of the draft of the article. FG participated in the analysis and interpretation of data. AS made critical revisions to the manuscript. NA did the literature review and reviewed the manuscript. IG participated in the conception and design of the study and in the acquisition of data, and reviewed the manuscript. MCHB participated in the acquisition of data and reviewed the manuscript.

\section{Acknowledgements}

This project was funded by the Yvelines Sud Mental Health Promotion Network (Réseau de promotion pour la santé mentale), the French National Institute of Health and Medical Research (INSERM), the MIRE-DREES, the National Center for Scientific Research (CNRS), and the European Commission. This project was registered with the French data protection authority (CNIL).

\section{References}

I. Steele LS, Glazier RH, Lin E: Inequity in mental health care under Canadian universal health coverage. Psychiatr Serv 2006, 57:317-324.

2. Jorm AF: Mental health literacy. Public knowledge and beliefs about mental disorders. Br J Psychiatry 2000, I77:396-40 I.

3. Angermeyer MC, Matschinger $\mathrm{H}$ : Have there been any changes in the public's attitudes towards psychiatric treatment? Results from representative population surveys in Germany in the years 1990 and 200 I. Acta Psychiatr Scand 2005, I I I:68-73.

4. Angermeyer MC, Breier P, Dietrich S, Kenzine D, Matschinger $\mathrm{H}$ : Public attitudes toward psychiatric treatment. An international comparison. Soc Psychiatry Psychiatr Epidemiol 2005, 40:855-864.

5. Alonso J, Angermeyer MC, Bernert S, Bruffaerts R, Brugha TS, Bryson $H$, de Girolamo G, Graaf R, Demyttenaere K, Gasquet I, Haro JM, Katz SJ, Kessler RC, Kovess V, Lepine JP, Ormel J, Polidori G, Russo LJ, Vilagut G, Almansa J, Arbabzadeh-Bouchez S, Autonell J, Bernal M, Buist-Bouwman MA, Codony M, Domingo-Salvany A, Ferrer M, Joo 
SS, Martinez-Alonso M, Matschinger H, Mazzi F, Morgan Z, Morosini P, Palacin C, Romera B, Taub N, Vollebergh WA: Use of mental health services in Europe: results from the European Study of the Epidemiology of Mental Disorders (ESEMeD) project. Acta Psychiatr Scand Suppl 2004:47-54.

6. Issakidis C, Andrews G: Who treats whom? An application of the Pathways to Care model in Australia. Aust N Z J Psychiatry 2006, 40:74-86.

7. Mickus M, Colenda CC, Hogan AJ: Knowledge of mental health benefits and preferences for type of mental health providers among the general public. Psychiatr Serv 2000, 5 I:199-202.

8. Priest RG, Vize C, Roberts A, Roberts M, Tylee A: Lay people's attitudes to treatment of depression: results of opinion pol for Defeat Depression Campaign just before its launch. $B M]$ 1996, 3 13:858-859.

9. Vasiliadis HM, Lesage A, Adair C, Boyer R: Service use for mental health reasons: cross-provincial differences in rates, determinants, and equity of access. Can / Psychiatry 2005, 50:6 I4-6I9.

10. Steel Z, McDonald R, Silove D, Bauman A, Sandford P, Herron J, Minas IH: Pathways to the first contact with specialist mental health care. Aust N ZJ Psychiatry 2006, 40:347-354

II. Kovess-Masféty V, Alonso J, Brugha TS, Angermeyer MC, Haro JM, Sevilla-Dedieu C, the ESEMeD/MHEDEA 2000 Investigators: Differences in the lifetime use of services for mental health problems in six European countries: results of the ESEMeD project. Psychiatr Serv 2007, 58:2 I3-220.

12. Goldberg D, Huxley P: Mental illness in the community: the pathway to psychiatric care. London, Tavistock Publications Ltd; 1980.

13. Verhaak PF: Determinants of the help-seeking process: Goldberg and Huxley's first level and first filter. Psychol Med 1995, 25:95-104.

14. Holmes AM, Deb P: Provider choice and use of mental health care: implications for gatekeeper models. Health Serv Res 1998, 33:1263-1284

15. Pescosolido BA, Gardner CB, Lubell KM: How people get into mental health services: stories of choice, coercion and "muddling through" from "first-timers". Soc Sci Med 1998, 46:275-286.

16. Albert M, Becker T, McCrone P, Thornicroft G: Social networks and mental health service utilisation--a literature review. Int J Soc Psychiatry 1998, 44:248-266.

17. Forsell $Y$ : The pathway to meeting need for mental health services in Sweden. Psychiatr Serv 2006, 57:114-119.

18. Vogel DL, Wester SR, Larson LM, Wade NG: An informationprocessing model of the decision to seek professional help. Prof Psychol Res Pr 2006, 37:398-406.

19. Korkeila J: Measuring aspects of mental health. Helsinki, National Research and Development Centre for Welfare and Health (Stakes); 2000.

20. Korkeila J, Lehtinen V, Bijl R, Dalgard OS, Kovess V, Morgan A, Salize $\mathrm{HJ}$ : Establishing a set of mental health indicators for Europe. Scand J Public Health 2003, 3 I:45 I-459.

2I. Oldendick RW, Bishop GF, Sorenson SB, Tuchfarber AJ: A comparison of the Kish and last birthday methods of respondent selection in telephone surveys. J Off Stat 1988, 4:307-318.

22. Kessler RC, Andrews G, Mroczek D, Ustun B, Wittchen HU: The World Health Organization Composite International Diagnostic Interview short-form (CIDI-SF). Int J Methods Psychiatr Res 1998, 7:171-185.

23. Mayfield D, McLeod G, Hall P: The CAGE questionnaire: validation of a new alcoholism screening instrument. Am J Psychiatry 1974, I3I:II2I-II 23.

24. Meltzer H: Development of a common instrument for menta health. In EUROHIS: Developing common instruments for health surveys Edited by: Nosikov A and Gudex C. Amsterdam, IOS Press; 2003.

25. Dowrick C, Casey P, Dalgard O, Hosman C, Lehtinen V, VazquezBarquero JL, Wilkinson G: Outcomes of Depression International Network (ODIN). Background, methods and field trials. ODIN Group. Br J Psychiatry 1998, 172:359-363.

26. Dalgard OS, Dowrick C, Lehtinen V, Vazquez-Barquero JL, Casey $P$, Wilkinson G, Ayuso-Mateos JL, Page H, Dunn G: Negative life events, social support and gender difference in depression: a multinational community survey with data from the ODIN study. Soc Psychiatry Psychiatr Epidemiol 2006, 41:444-45I.
27. Angermeyer MC, Matschinger H, Riedel-Heller SG: Whom to ask for help in case of a mental disorder? Preferences of the lay public. Soc Psychiatry Psychiatr Epidemiol 1999, 34:202-210.

28. World Health Organization: Mental Health Atlas 2005. Geneva, World Health Organization; 2005.

29. Leaf PJ, Bruce ML, Tischler GL, Holzer CE 3rd.: The relationship between demographic factors and attitudes toward mental health services. J Community Psychol 1987, 1 5:275-284.

30. Tijhuis MA, Peters L, Foets M: An orientation toward help-seeking for emotional problems. Soc Sci Med 1990, 31:989-995.

31. Angermeyer MC, Matschinger H: Public attitude towards psychiatric treatment. Acta Psychiatr Scand 1996, 94:326-336.

32. Jorm AF, Korten AE, Rodgers B, Pollitt P, Jacomb PA, Christensen $H$, Jiao $Z$ : Belief systems of the general public concerning the appropriate treatments for mental disorders. Soc Psychiatry Psychiatr Epidemiol 1997, 32:468-473.

33. Angermeyer MC, Daumer R, Matschinger H: Benefits and risks of psychotropic medication in the eyes of the general public: results of a survey in the Federal Republic of Germany. Pharmacopsychiatry 1993, 26: I |4-120.

34. Ohayon MM, Lader MH: Use of psychotropic medication in the general population of France, Germany, Italy, and the United Kingdom. I Clin Psychiatry 2002, 63:817-825.

35. Olié JP, El Omari F, Spadone C, Lépine JP: Results of a survey about antidepressant use in the general Franch population. L'Encéphale 2002, 28:4II-4I7.

36. Bayer JK, Peay MY: Predicting intentions to seek help from professional mental health services. Aust N Z J Psychiatry 1997. 31:504-5I3.

37. Younes N, Gasquet I, Gaudebout P, Chaillet MP, Kovess V, Falissard B, Hardy Bayle MC: General practitioners' opinions on their practice in mental health and their collaboration with mental health professionals. BMC Fam Pract 2005, 6: I8.

38. Paykel ES, Tylee A, Wright A, Priest RG, Rix S, Hart D: The Defeat Depression Campaign: psychiatry in the public arena. $\mathrm{Am} J$ Psychiatry 1997, 154:59-65.

39. Paykel ES, Hart D, Priest RG: Changes in public attitudes to depression during the Defeat Depression Campaign. BrJ Psychiatry 1998, 173:519-522.

\section{Pre-publication history}

The pre-publication history for this paper can be accessed here:

\section{http://www.biomedcentral.com/1471-2458/7/188/pre} pub

Publish with Biomed Central and every scientist can read your work free of charge

"BioMed Central will be the most significant development for disseminating the results of biomedical research in our lifetime. "

Sir Paul Nurse, Cancer Research UK

Your research papers will be:

- available free of charge to the entire biomedical community

- peer reviewed and published immediately upon acceptance

- cited in PubMed and archived on PubMed Central

- yours - you keep the copyright
BioMedcentral 